\title{
Analysis of tourism potential and ecological tourism development in Kazakhstan
}

\author{
Lyailya Mutaliyeva ${ }^{1, *}$, Nurlan Kurmanov ${ }^{1}$, Aruana Akisheva ${ }^{1}$ \\ ${ }^{1}$ L.N. Gumilyov Eurasian National University, 010008 Satpayev 2 Str., Nur-Sultan, Kazakhstan
}

\begin{abstract}
This article analyzes the tourism potential and ecological tourism development in Kazakhstan on the example of the Kostanay region. To analyze the consumers of tourism products and services in the region, a sociological survey was conducted to determine the preferences of local residents. The aim of this study is to determine the interests, potential and attitude of the domestic market to the ecological tourism development in Kazakhstan. According to the results, it was revealed that the Kostanay region's natural and historical sights has a rich potential for cultural and natural heritage. However, in the region there are problems of the further ecological tourism development: underdeveloped tourism infrastructure; the lack of systematic measures for the tourism development by the state body; problems with training for the industry.
\end{abstract}

\section{Introduction}

The unique tourist and recreational potential of the Republic of Kazakhstan requires targeted and scientifically sound use. The domestic ecological tourism development in the country on the basis of the existing infrastructure and network has great prospects and may become the basis for their sustainable development of tourism enterprises. Currently, in order to confirm the tourism industry development in the country, it is necessary to clearly identify promising ecological tourism destinations with potential, which should be reflected in the mechanism for managing the ecological tourism development. The opportunities in the ecological tourism development are great. However, this sector in the overall structure of the economy, socio-economic life of the country remains not fully in demand. This requires improving the mechanism for managing the ecological tourism development, which should take into account the interests of the local population and regional characteristics, as well as be aimed at strengthening the interaction of business and the State in these matters.

\section{Brief Literature Review}

In modern conditions, a new type of tourism, which the market has not yet fully demanded, is ecological tourism.

\footnotetext{
*Corresponding author: mutalieva_leila@mail.ru
} 
Ecotourism management is also taking its first steps. Important at first, according to many researchers $[1,2,3,4,5]$, is to recognize the role and place of management in environmental tourism, to identify its features.

Literature review showed $[6,7,8,9,10,11]$ that the establishment of ecotourism management is associated with the following circumstances.

1) Innovation is apprehended cautiously by those who already have their own niche in tourism.

2) Ecotourism, entering the tourist market, is associated at first with high costs, which makes it elite and too expensive.

3) It is necessary to reckon, speaking about ecological tourism, with its specificity, which will require efforts to occupy its niche in the market.

This implies the important conclusion that ecotourism management should have greater "punch" ability, which should be based on the high quality of this type of tourism product.

Some researchers $[12,13,14,15,16,17,18]$ distinguish the following target orientation of ecotourism management.

Firstly, the ecological tourism management should pay special attention to improving the culture of relations between tourists and nature, environmental education through the development and implementation of behavior standards in the natural environment, as well as a meaningful study of tourist environmental programs.

Secondly, the ecological tourism management should be set up to fully promote the tourist centers development (State natural resources, specially protected natural areas).

Thirdly, the ecotourism management should act as a protector of nature in the tourist territories (the concept of "green marketing").

Fourth, the ecological tourism management, creating and implementing cost-effective tourism services and products, focusing on making a profit, striving to minimize costs, should proceed from the consideration that not only this determines the whole point of ecological tourism activities. Businesses should also consider and adhere to environmental functions.

\section{Materials and methods}

To analyze the consumers of tourism products and services in Kazakhstan, a sociological survey was conducted to determine the preferences of the Kostanay region residents.

The study purpose was to determine the interests, potential and attitude of the domestic market to the eco-tourism development in Kazakhstan on the example of the Kostanay region.

Based on the study purpose, the following tasks were set:

- Determine the preferences of the region residents in organizing holidays and weekends;

- Identify weaknesses in the environmental recreation organization, tourism infrastructure of the Kostanay region;

- To develop recommendations on creating favorable conditions for the ecological tourism development in the Kostanay region. region.

The study object is the main components of the ecotourism industry in the Kostanay

The study subject is the opinion of residents and guests about the tourist orientation of the Kostanay region.

The research methodology involved the collection of primary information (table 1).

Table 1. Respondents who participated in the survey

\begin{tabular}{|l|c|}
\hline Target group & Residents and guests of the Kostanay region \\
\hline Methodology & Opinion poll \\
\hline
\end{tabular}




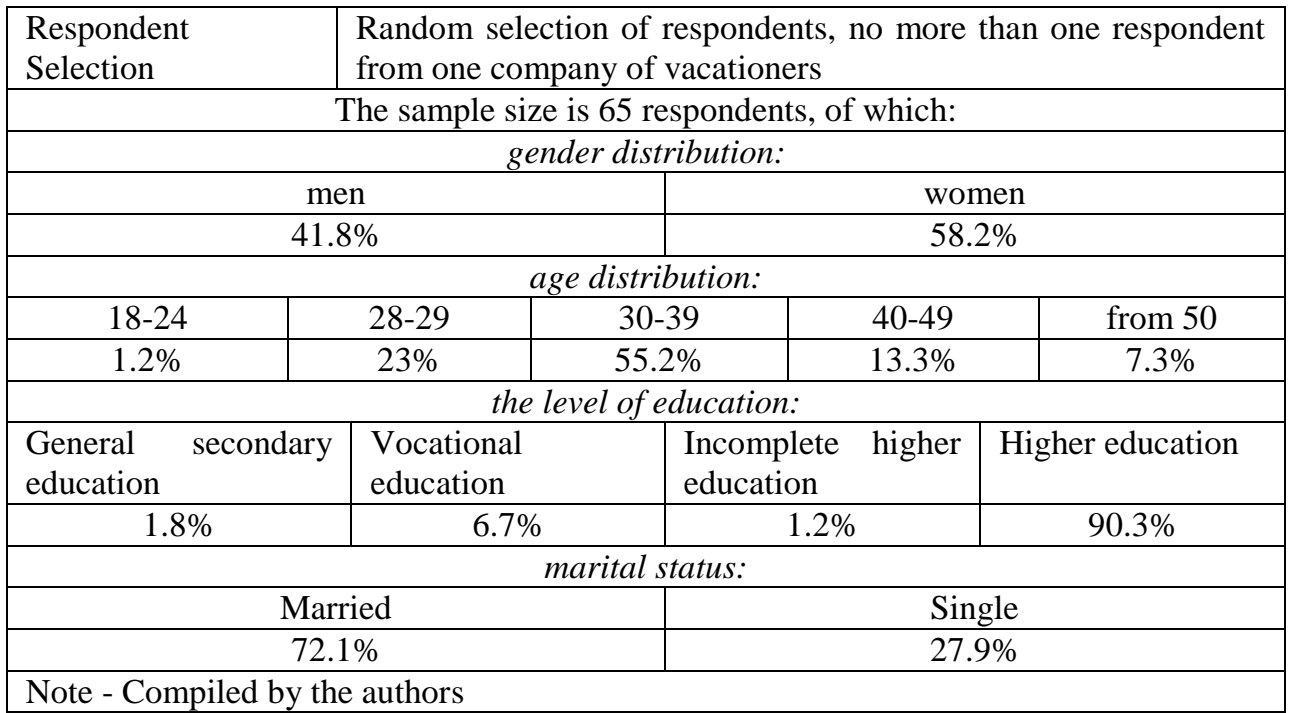

\section{Results and discussion}

According to the results of a sociological survey, it was found that $30.0 \%$ of residents of the Kostanay region prefer to spend their holidays in the countryside with their parents or other relatives, $26.9 \%$ of the region's residents in other countries, $21.9 \%$ of the region's residents spend their holidays at home (Figure 1).

Spend a vacation with parents (relatives) in the village

Spend holidays in other countries

Spend a vacation at home

Spend a vacation in the country at camp sites, recreation areas
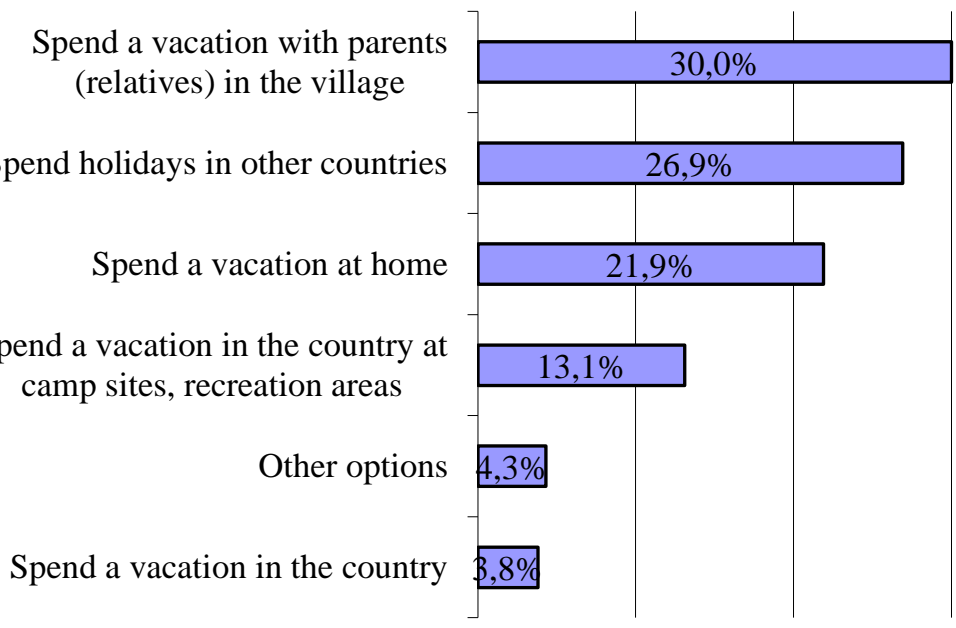

Fig. 1. Preferences of the Kostanay region's residents and guests on vacation Note - Compiled by the authors

Spending vacations in other countries, residents and guests of the region most often prefer to relax in the resorts of Turkey, in Europe and Russia. $4.3 \%$ of respondents indicated that they spend their vacation in Kazakhstan as other options.

During the holidays, in addition to rest, $88 \%$ of the region's residents go on weekends to rest outside the city. Of these, $47 \%$ of vacationers go with family and friends to nature (in the forest, to the reservoir) for a picnic, $23 \%$ go to summer cottages for leisure activities. Only $17 \%$ of people travel with family and friends to camp sites and recreation areas. 
Residents of the region who travel outside the city on their weekends to do this on average 1-2 times a month.

Kostanay region's residents, staying in the city on weekends, prefer mainly to do household chores, walk in parks and squares, spend time with their families, visit cinemas and shopping and entertainment centers, and visit friends and relatives. On weekends, some residents of the region prefer to stay in the city and go in for sports: visiting pools, rollerblading, cycling around the city, etc.

On average, residents of the region are ready to spend about 7,500 tenge per family member for a vacation. At the same time, we note that the range of spending on vacation ranged from 1000 tenge to 50,000 tenge. Residents of the region, while remaining in the city, are ready to spend a little more on 1 family member - about 8300 tenge.

During a sociological survey of the region's potential tourists, it was revealed what natural and cultural attractions they know. As a result, it was determined that the most famous attractions of the region are the Sosnovy Bor sanatorium and the Naurzum reserve (Figure 2).

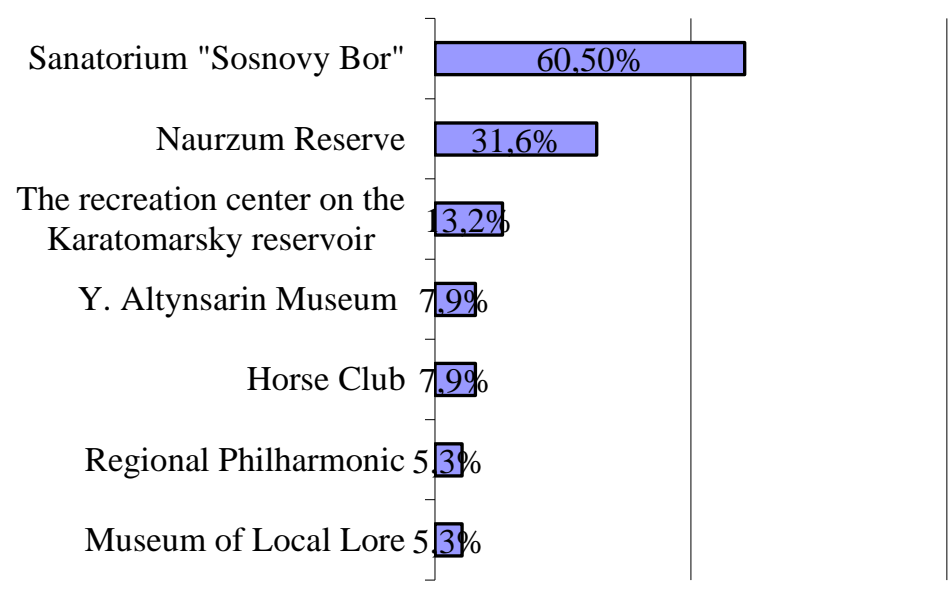

Fig. 2. Kostanay region's places of rest and attractions known to potential tourists Note - Compiled by the authors

We can conclude that the popularity of recreation and attractions places among Kostanay region's potential tourists is not high. This is confirmed by the answers of respondents regarding places of rest and attractions that they would like to visit in the region. The interviewed respondents indicated the sanatorium "Sosnovy Bor", the recreation center "Golden Fish" on the Karatomarsky reservoir.

As part of a sociological survey of potential tourists in the Kostanay region, a study was conducted regarding the views on tourism development opportunities in the region, including environmental and priority measures to create favorable conditions for this.

As part of a sociological study, an assessment of development in the field of individual components of the tourism industry was determined. The assessment was carried out using a five-point scale, where:

-5 points - well developed.

- 1 point - not developed at all.

To analyze the collected data, the following gradation was used:

- from 4 to 5 points - a high level of development.

- 3-4 points - the average level of development,

- 1 to 3 points - low level of development. 
As a result of the analysis, we can conclude that, according to residents, all tourism industry components in the region are at an average or low level. According to the respondents, roads, public transport, recreation areas and tourist centers, galleries and museums have a low level of development (Figure 3).

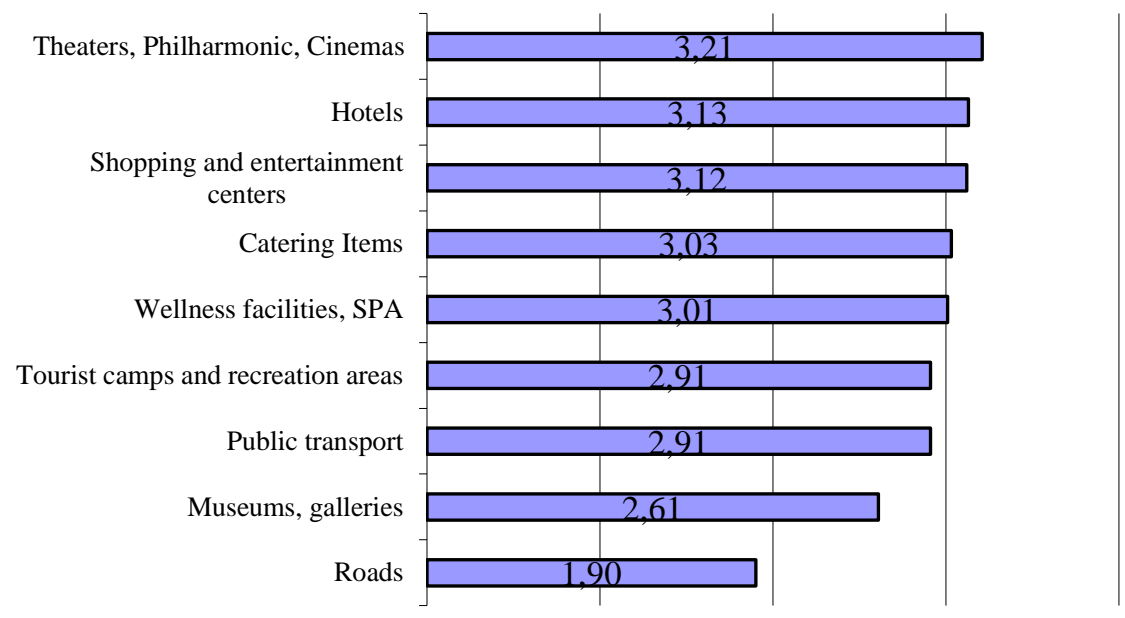

Fig. 3. Assessment of the level constituent element of the tourism industry development in the Kostanay region by residents of the region

Note - Compiled by the authors

To determine the resident's opinion on the tourism development in the region, it was proposed to identify areas of tourism that can develop in the Kostanay region. The following areas of tourism development were proposed as options: Cognitive tourism, Sports tourism, Ecological tourism, Ethnographic tourism, Health-improving tourism, Business tourism, Shopping, Educational tourism, Event tourism (Figure 4).

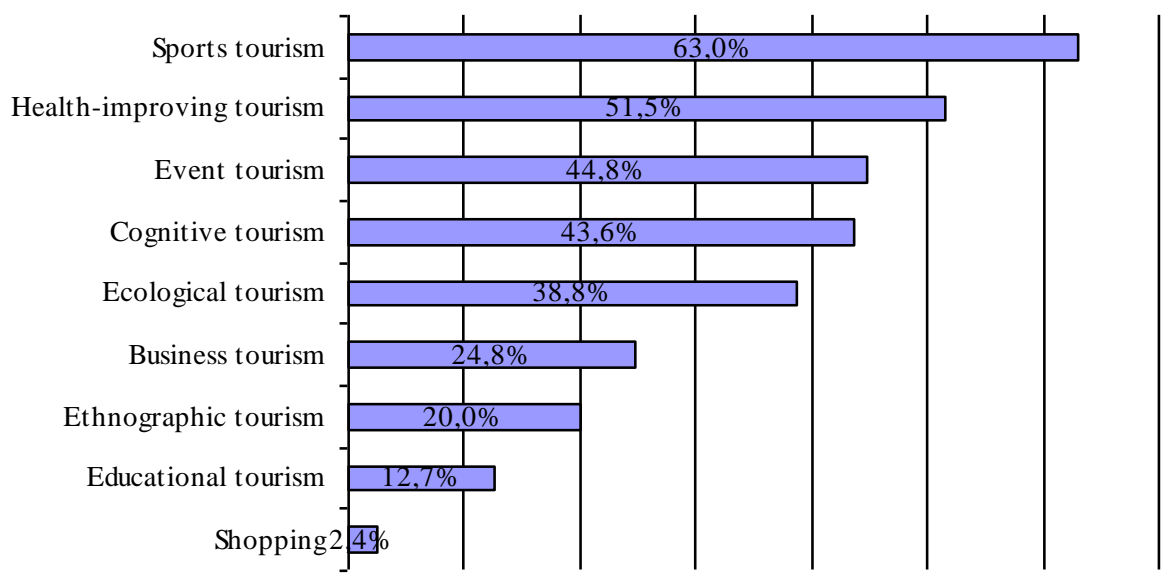

Fig. 4. Destinations of tourism those are possible for development in the Kostanay region Note - Compiled by the authors

So, the residents identified the following five as key areas: sports tourism, healthimproving tourism, event tourism, educational tourism, ecological tourism. 
In addition, in the framework of a sociological survey, the directions of improvement and changes that are necessary in the Kostanay region for more efficient development of the tourism industry were identified (Figure 5).

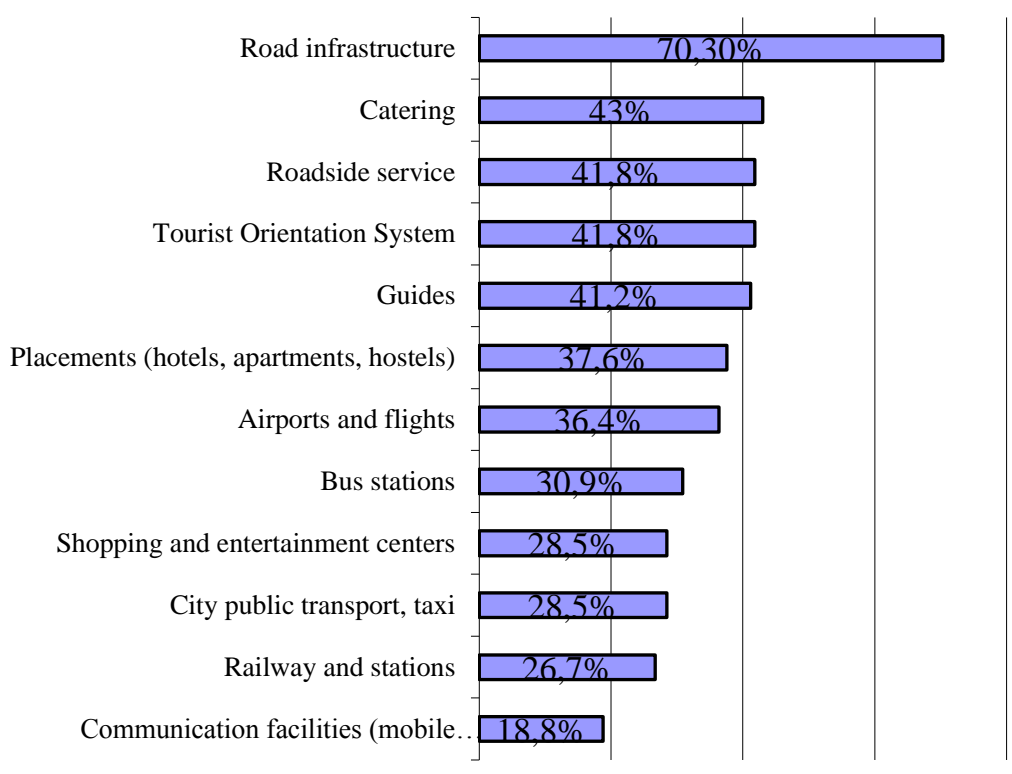

Fig. 5. Improvements and changes necessary for more effective ecological tourism industry development in the Kostanay region

Note - Compiled by the authors

Thus, residents of the Kostanay region of Kazakhstan believe that in order to develop tourism in the region, it is first of all necessary to improve road infrastructure, the activities of public catering facilities, roadside services, a tourist orientation system, and the provision of guides and guides.

\section{Conclusion}

The article examined the tourism potential of the Kostanay region.

It is established that the Kostanay region has rich natural and historical potential for tourism development. So, in the region there are 514 objects of cultural heritage and 726 cultural and historical monuments.

The problems of the ecological tourism development in the region are identified:

- Lack of a developed hotel and restaurant industry in the region.

- Underdeveloped tourism infrastructure in the regions.

- Lack of systematic measures for the development of tourism in the region by the authorized body.

- Lack of measures taken to protect, preserve and restore natural and cultural-historical objects.

- Irrational nature management.

- Lack and / or poor condition of roads leading to major tourist destinations.

There are also problems with training for the industry. It is difficult to find professional guides in the region who speak the Kazakh and foreign languages, few guides who are able to conduct a quality tour in the Kazakh language. 
It was determined that for the development of tourism in the region, it is first of all necessary to improve road infrastructure, the activities of public catering enterprises, roadside services, a tourist orientation system, and the provision of guides and guides.

The solution to these problems lies in strengthening the interaction between the subjects of government in the industry - tourism enterprises and the state.

\section{References}

1. N. Nikiforova, M. Smykova, L. Mutaliyeva, K. Mussina, Journal of Environmental Management and Tourism, 10:2, 354-359 (2019)

2. T.A. Kussainov, M. Maitah, N.A. Kurmanov, P. Hájek, B.S. Tolysbaev, A.K. Baidakov, Review of European Studies, 7:11, 125-131 (2015) doi:10.5539/res.v7n11p125

3. A. Yeleussov, N. Kurmanov, B. Tolysbayev, Actual Problems of Economics, 2:164, 142-150 (2015)

4. L. M. Baitenova, M. R. Smykova, L. M. Mutaliyeva, Actual Problems in Economics, 178, 97-103 (2016)

5. N. Kurmanov, B. Tolysbayev, D. Aibossynova, N. Parmanov, Economic Annals - XXI, 158:3-4, 57-61 (2016) DOI: http://dx.doi.org/10.21003/ea.V158-13

6. A.K. Maralov, K.A. Kirdasinova, N. Kurmanov, G. Kabdullina, M. Uandykova, International Journal of Supply Chain Management, 8:2, 268-276, (2019)

7. N. Kurmanov, B. Beisengaliyev, A. Dogalov, D. Turekulova, N. Kurmankulova, International Journal of Economics and Financial Issues, 6:4, 1440-1445 (2016)

8. S. S. Baktymbet, A. S. Baktymbet, N. A. Kurmanov, A. Zh. Satbayeva, Bulletin of the National Academy of Sciences of the Republic of Kazakhstan, 2, 160-169 (2017)

9. N. Kurmanov, U. Aliev, S. Suleimenov, Polish Journal of Management Studies, 19:1, 204-214 (2019) DOI: 10.17512/pjms.2019.19.1.15

10. N. Kurmanov, M. Petrova, S. Suleimenova, E3S Web Conf., 105, 04045 (2019) https://doi.org/10.1051/e3sconf/201910504045

11. K. P. Mussina, L. M. Mutaliyeva, A. Z. Assylkhanova, Z. B. Teleubay, L. M. Baitenova, Espacios, 40:6, 1-11 (2019).

12. N. Kurmanov, A. Yeleussov, U. Aliyev, B. Tolysbayev, Mediterranean Journal of Social Sciences, 6:5 (S1), 54-61 (2015) Doi:10.5901/mjss.2015.v6n5s1p54

13. N. Kurmanov, U. Aliyev, A. Rakhimbekova, A. Makhatova, Bulletin of the National Academy of Sciences of the Republic of Kazakhstan, 5, 46-54 (2016)

14. S. S. Baktymbet, N. A. Kurmanov, A. S. Baktymbet, Bulletin of the National Academy of Sciences of the Republic of Kazakhstan, 4, 141-149 (2016)

15. N. Kurmanov, D. Turekulova, G. Doskeyeva, G. Alina, International Journal of Economics and Financial Issues, 6:3, 907-910 (2016)

16. N. A. Kurmanov, B. K. Zhumanova, O. V. Kirichok, World Applied Sciences Journal, 21:10, 1495-1501 (2013) DOI: 10.5829/idosi.wasj.2013.21.10.2952

17. V. Annenkova, I. Subbotina, L. Mutaliyeva, A. Isaeva, International Journal of Civil Engineering and Technology, 10:2, 1979-1987 (2019)

18. N. Kurmanov, VIth Ryskulov Readings: Socio-Economic Modernization of Kazakhstan under conditions of global financial instability, 1186-1198 (2012) 